\section{OPEN ACCESS}

Edited by:

Sagadevan G. Mundree,

Queensland University of Technology,

Australia

Reviewed by:

Kashmir Singh,

Panjab University, Chandigarh, India Gautam Sarath,

United States Department of Agriculture - Agricultural Research Service, USA

*Correspondence. Manoj K. Sharma mksharma@jnu.ac.in

Specialty section: This article was submitted to

Plant Biotechnology,

a section of the journal

Frontiers in Plant Science

Received: 26 March 2016

Accepted: 29 August 2016 Published: 13 September 2016

Citation:

Sharma R, Wungrampha S, Singh V, Pareek A and Sharma MK (2016) Halophytes As Bioenergy Crops. Front. Plant Sci. 7:1372 doi: 10.3389/fp/s.2016.01372

\title{
Halophytes As Bioenergy Crops
}

\author{
Rita Sharma ${ }^{1}$, Silas Wungrampha ${ }^{2}$, Vinay Singh ${ }^{3}$, Ashwani Pareek ${ }^{2}$ and \\ Manoj K. Sharma ${ }^{3 *}$ \\ ${ }^{1}$ School of Computational and Integrative Sciences, Jawaharlal Nehru University, New Delhi, India, ${ }^{2}$ Stress Physiology and \\ Molecular Biology Laboratory, School of Life Sciences, Jawaharlal Nehru University, New Delhi, India, ${ }^{3}$ School of \\ Biotechnology, Jawaharlal Nehru University, New Delhi, India
}

Shrinking arable land due to soil salinization and, depleting fresh water resources pose serious worldwide constraints to crop productivity. A vision of using plant feedstock for biofuel production can only be realized if we can identify alternate species that can be grown on saline soils and therefore, would not compete for the resources required for conventional agriculture. Halophytes have remarkable ability to grow under high salinity conditions. They can be irrigated with seawater without compromising their biomass and seed yields making them good alternate candidates as bioenergy crops. Both oil produced from the seeds and the lignocellulosic biomass of halophytes can be utilized for biofuel production. Several researchers across the globe have recognized this potential and assessed several halophytes for their tolerance to salt, seed oil contents and composition of their lignocellulosic biomass. Here, we review current advances and highlight the key species of halophytes analyzed for this purpose. We have critically assessed the challenges and opportunities associated with using halophytes as bioenergy crops.

Keywords: biofuel, halophytes, lignocellulosic biomass, oilseed, salinity

\section{INTRODUCTION}

Uninterrupted supply of energy is a prerequisite to global technological and economic development. However, with increasing population and energy consumption rates, fossil fuel-based energy resources may only last a few more decades. Also, limited stocks and environmental hazards associated with the usage of fossil fuels have led to global interest in exploring renewable and greener sources of energy (van der Weijde et al., 2013). Plant-based biofuels are greener alternative to fossil fuels with potential to mitigate global warming and climate change (Sagar and Kartha, 2007).

Depending upon the source of the raw material, biofuels are classified into different generations. The first generation biofuels are derived from plant sugars, starchy grains and vegetable oils using conventional technologies (Naik et al., 2010). However, since these plant products are also used as animal feed or food, there is a growing concern that their diversion to produce biofuels may lead to global food shortages and, rise in food prices. To deal with the food vs. fuel dilemma, interest was shifted to use of non-food biomass for the production of second generation biofuels (Chundawat et al., 2011). The source of second-generation biofuels could be lignocellulosic biomass or nonfood oilseed crops, for example Pongamia, Jatropha, etc. The lignocellulosic biomass includes agricultural waste in the form of crop straw, husks, forest residue or dedicated perennial grasses such as switchgrass and Miscanthus, grown on marginal lands (Hadar, 2013). The production of fuel from these sources has huge potential to minimize environmental footprint, improve 
soil quality and create high-skilled jobs in the area of technology development and processing. However, high lignin content in these crops is a major cause of recalcitrance for conversion to ethanol. Also, the technology for biochemical conversion of lignocellulosic biomass is expensive and still under development (Simmons et al., 2008; Chundawat et al., 2011). Major limitation with these crops is that they would create an unwarranted and undesirable competition for arable land and fresh water resources used for conventional agriculture. Therefore, large scale planting of bioenergy crops, requiring fresh water resources, may not be feasible (Foley et al., 2005; Koonin, 2006; Kennedy, 2007).

In spite of the fact that over $70 \%$ of the earth is covered with water, majority is not suitable for irrigation or human consumption due to high salinity. Further, we have limited area of arable land and its further salinization due to continuous irrigation (that brings dissolved salts) is a major constraint to agricultural production (Flowers and Colmer, 2008). According to a recent estimate, salinized land has increased from $\sim 45$ to $\sim 62$ million ha in last two decades, which is about $20 \%$ of the globally irrigated land (Qadir et al., 2014). Over 800 million hectare of the world comprising coastal tideland is also affected by salinity. Clearly, if we can utilize this huge amount of unused niche space for growing biofuel feedstocks that can be irrigated with seawater, we can actually overcome major hurdles associated with farming for biofuels (Rozema and Flowers, 2008).

Based on his experiments in Israel, the ecologist Hugo Boyko showed that several plant species can be irrigated with the salt water (Boyko, 1967). His idea stimulated a global interest to explore the constraints posed by salinity and led to systematic identification of plant species that can grow under saline conditions (Malcolm, 1969; Nielsen et al., 1977; Gallagher, 1985; Pasternak et al., 1985; Glenn et al., 1996). The unique category of plants that can grow, reproduce and thrive well in habitats with very high salt concentrations where most of the other plant species don't survive, are widely known as halophytes. Recently, Ventura et al. (2014) have reviewed the history and scope of halophyte-based agriculture. The tolerance of halophytes to salt varies in different species and stages of development. Halophytes are widely distributed in the coastal regions, marshy soils, mangroves swamps, estuaries, and saline semi deserts (O'leary and Glenn, 1994; Glenn et al., 1999). They can flourish well in soils ranging from normal to severely saline. Some halophytes can even grow well at salt concentrations higher than that of seawater (>500 mM; Sabovljevic and Sabovljevic, 2007). Interestingly, dicot halophytes are more tolerant as compared to monocot species and exhibit optimal growth in 100-200 mM $\mathrm{NaCl}$, whereas, monocotyledonous halophytes show optimal growth in $50-100 \mathrm{mM}$ of $\mathrm{NaCl}$ (Bell and O'Leary, 2003; Flowers and Colmer, 2008).

The number of halophyte species is estimated to range from 2000 to 3000 (Sabovljevic and Sabovljevic, 2007) and majority of them belong to angiosperms. During 1980s, James Aronson compiled a comprehensive database of 1554 halophyte species, termed as HALOPH (Aronson and Whitehead, 1989). This has recently been converted to an interactive eHALOPH database (Santos et al., 2016) that also provides a bibliography of literature available for the halophytes.
Although, halophytes represent less than $2 \%$ of the land plant population, they can be used for several commercial purposes such as vegetables, medicinal value, ornamental landscaping, environmental protection and wild life support (Flowers and Colmer, 2008; Cassaniti and Romano, 2011; Koyro et al., 2011; Ladeiro, 2012; Cassaniti et al., 2013; Panta et al., 2014; Ventura et al., 2014). Halophytes have a huge potential to rehabilitate the salt-affected lands and in phytoremediation of polluted soils (Hasanuzzaman et al., 2014; Panta et al., 2014). Due to their unique ability to thrive in saline soils and positive impact on environment, halophytes are potentially good candidates for biofuel production. Some of the halophytes, known as salt accumulators, store salts in their organs as an adaptive mechanism; while others have developed ways to exclude it (Touchette et al., 2009). The salt excluders are in general better choice for biofuels, because non-combustible content of the biomass produced from accumulators may lead to fouling problems.

Due to their unlimited potential, several halophytes species have been screened for large-scale production in different parts of the world and to breed new crops for saline lands. Xian-zhao et al. (2012) reviewed the distribution of major halophytic energy plants in coastal zone of China and assessed their potential for developing energy plants for bioethanol production. Similar surveys have been done in other countries leading to identification of potential halophyte species. Some of the most promising genera are Salicornia (glasswort), Suaeda (sea-blite), Atriplex (saltbush), arid salt grass Distichlis and succulent leaved ground cover Batis (Squires and Ayoub, 1994; Glenn et al., 1998; Parida and Das, 2005; Rozema and Flowers, 2008; Abideen et al., 2011). Both oilseeds and lignocellulosic biomass produced by halophytes can be used for the production of biofuels. Table 1 summarizes the halophytes that have been screened for the oil content and composition of lignocellulosic biomass. In several species like Salicornia bigelovii, both seed oil and lignocellulosic biomass can be effectively converted into biofuels (Panta et al., 2014). Here, we have summarized the current status of biofuel research with halophytes and highlighted major challenges and opportunities in the area.

\section{HALOPHYTES FOR OIL}

Plant seed oil is a very good resource for the production of biodiesel. In fact, several plant species like canola, mustard, soybean etc. have already been explored for this purpose (Blackshaw et al., 2011). Many halophyte species (Table 1A) for example, Suaeda aralocaspica, Salicornia bigelovii, Crithmum maritimum, Ricinus communis, Euphorbia tirucalli, Kosteletzkya virginica, and Descurainaia sophia can store high concentrations of oils accounting for $>20 \%$ of the total dry seed weight (Abideen et al., 2012, 2014). Studies show that the fatty acid methyl ester composition of oils extracted from halophytes is comparable to the other oil crops used for production of biodiesel (Abideen et al., 2012; Gul et al., 2013). The yield of oil varies in different species. Ricinus communis accumulates exceptionally 
TABLE 1 | List of Halophyte species assessed for oil and lignocellulosic biomass yields.

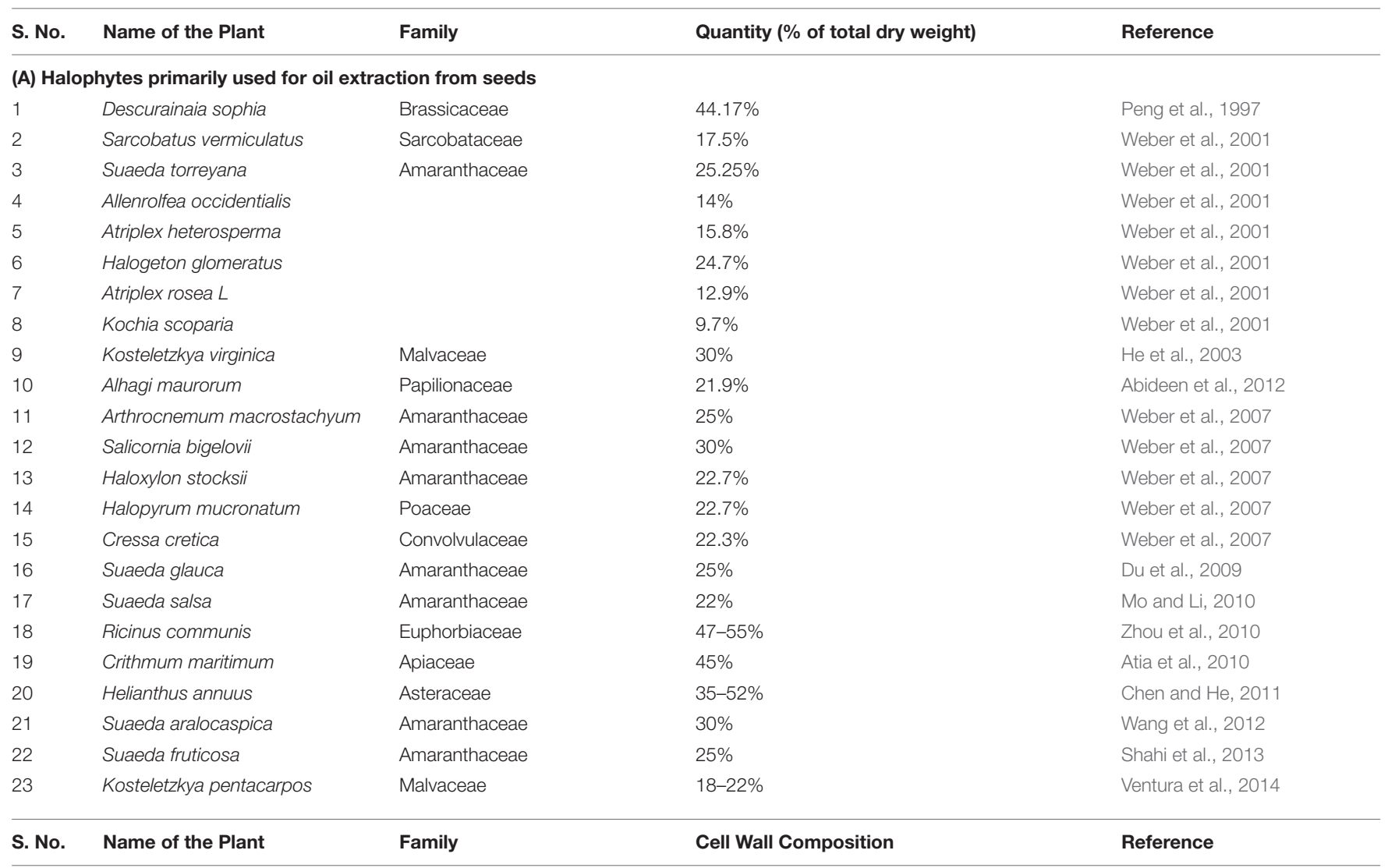

(B) Halophytes primarily used for lignocellulosic biomass (CL, Cellulose; HC, Hemicellulose and LG, Lignin)

\begin{tabular}{|c|c|}
\hline Panicum virgatum & Poaceae \\
\hline Phragmites australis & Poaceae \\
\hline Aeluropus lagopoides & Poaceae \\
\hline Aerva javanica & Amaranthaceae \\
\hline Arthrocnemum indicum & Amaranthaceae \\
\hline Calotropis procera & Apocynaceae \\
\hline Cenchrus ciliaris & Poaceae \\
\hline Chloris barbata & Poaceae \\
\hline Desmostachya bipinnata & Poaceae \\
\hline Dichanthium annulatum & Poaceae \\
\hline Eleusine indica & Poaceae \\
\hline Halopyrum mucronatum & Poaceae \\
\hline Ipomea pes-caprae & Convolvulaceae \\
\hline Lasiurus scindicus & Poaceae \\
\hline Panicum turgidum & Poaceae \\
\hline Paspalum paspaloides & Poaceae \\
\hline Phragmites karka & Poaceae \\
\hline Salsola imbricata & Amaranthaceae \\
\hline Salvadora persica & Salvadoraceae \\
\hline Sporobolus ioclados & Poaceae \\
\hline Suaeda monoica & Amaranthaceae \\
\hline Suaeda fruticosa & Amaranthaceae \\
\hline Tamarix indica & Tamaricaceae \\
\hline Typha domingensis & Poaceae \\
\hline Urochondra setulosa & Poaceae \\
\hline Miscanthus spp. & Poaceae \\
\hline Achnatherum splendens & Poaceae \\
\hline
\end{tabular}

$45 \% \mathrm{CL}, 31 \% \mathrm{HC}$ and $12 \% \mathrm{LG}$

$50 \% \mathrm{CL}$ and $17 \%$ LG

$26.67 \% \mathrm{CL}, 29.33 \% \mathrm{HC}$ and $7.67 \% \mathrm{LG}$

$15.67 \% \mathrm{CL}, 13.33 \% \mathrm{HC}$ and $6.33 \% \mathrm{LG}$

$11.33 \% \mathrm{CL}, 13.00 \% \mathrm{HC}$ and $7.00 \% \mathrm{LG}$

$12.33 \% \mathrm{CL}, 11.00 \% \mathrm{HC}$ and $5.00 \% \mathrm{LG}$

$22.67 \% \mathrm{CL}, 23.17 \% \mathrm{HC}$ and $7.00 \% \mathrm{LG}$

25.33\% CL, 23.00\% HC and 8.33\% LG

$26.67 \% \mathrm{CL}, 24.68 \% \mathrm{HC}$ and $6.67 \% \mathrm{LG}$

$19.00 \% \mathrm{CL}, 24.33 \% \mathrm{HC}$ and $7.00 \% \mathrm{LG}$

$22.00 \% \mathrm{CL}, 29.67 \% \mathrm{HC}$ and $7.00 \% \mathrm{LG}$

$37.00 \% \mathrm{CL}, 28.67 \% \mathrm{HC}$ and $5.00 \% \mathrm{LG}$

$12.67 \% \mathrm{CL}, 17.00 \% \mathrm{HC}$ and $5.33 \% \mathrm{LG}$

$24.67 \% \mathrm{CL}, 29.67 \% \mathrm{HC}$ and $6.00 \% \mathrm{LG}$

$28.00 \% \mathrm{CL}, 27.97 \% \mathrm{HC}$ and $6.00 \%$ LG

$20.33 \% \mathrm{CL}, 33 \% \mathrm{HC}$ and $2.33 \%$ LG

$26.00 \% \mathrm{CL}, 29.00 \% \mathrm{HC}$ and $10.33 \% \mathrm{LG}$

9.00\% CL, $18.33 \% \mathrm{HC}$ and $2.67 \% \mathrm{LG}$

$22.00 \% \mathrm{CL}, 13.33 \% \mathrm{HC}$ and $7.00 \% \mathrm{LG}$

$15.33 \% \mathrm{CL}, 30.67 \% \mathrm{HC}$ and $2.00 \% \mathrm{LG}$

$10.67 \% \mathrm{CL}, 11.33 \% \mathrm{HC}$ and $2.33 \% \mathrm{LG}$

8.67\% CL, 21.00\% HC and $4.67 \%$ LG

$12.17 \% \mathrm{CL}, 24.67 \% \mathrm{HC}$ and $3.33 \% \mathrm{LG}$

26.33\% CL, 38.67\% HC and $4.67 \%$ LG

25.33\% CL, 25.00\% HC and 6.33\% LG

40-60\% CL, 20-40\% HC and 10-30\% LG

$16.7 \%$ LG
McLaughlin and Kszos, 2005

Yan et al., 2010

Abideen et al., 2011

Abideen et al., 2011

Abideen et al., 2011

Abideen et al., 2011

Abideen et al., 2011

Abideen et al., 2011

Abideen et al., 2011

Abideen et al., 2011

Abideen et al., 2011

Abideen et al., 2011

Abideen et al., 2011

Abideen et al., 2011

Abideen et al., 2011

Abideen et al., 2011

Abideen et al., 2011

Abideen et al., 2011

Abideen et al., 2011

Abideen et al., 2011

Abideen et al., 2011

Abideen et al., 2011

Abideen et al., 2011

Abideen et al., 2011

Abideen et al., 2011

Brosse et al., 2012

Xian-zhao et al., 2012 
high concentration of seed oils up to $40 \%$ of the total seed dry weight (Zhou et al., 2010; Abideen et al., 2014). Another halophyte species, S. bigelovii (pickle weed, sea asparagus or glasswort) produces about 2 ton seeds per hectare and can store oils up to $30 \%$ of the total dry weight (Glenn et al., 1999). Euphorbia tirucalli, a dicot plant, is estimated to have equal or even higher yields when grown on salt water than most of the oilseed crops irrigated using fresh water (Khaleghian et al., 2011). Perennial halophyte, Kosteletzkya pentacarpos, is also under investigation for biodiesel production from seeds and cellulosic ethanol from biomass (Moser et al., 2013). Its seeds contain about $20 \%$ oil and the disease susceptibility of the plant is very low. Kosteletzkya virginica is a perennial dicot halophyte with yields up to $1500 \mathrm{~kg}$ per hectare. Oil comprises of about $22 \%$ of the total dry weight of its seeds (Gallagher, 1985; Ruan et al., 2008). About 40 years ago, Melvin Calvin's group had recommended Euphorbia tirucalii (a desert succulent) as a potential biofuel crop (Nielsen et al., 1977). It is currently being explored for its potential with saline sewage irrigation and has been shown to produce high amounts of secondary metabolites, which can be directly converted to biofuels (Eshel et al., 2010; Eschel et al., 2011; Hastilestari et al., 2013).

\section{HALOPHYTES FOR LIGNOCELLULOSIC BIOMASS}

Lignocellulosic biomass is plant's dry matter mainly comprising of cellulose, hemicellulose and lignin. In the recent past, several salt tolerant plant species have been identified with the potential to produce huge biomass on the salinityaffected lands (Qadir et al., 2008; Liu et al., 2012; Ventura et al., 2014). These include Tamarix chinensis, Halopyrum mucronatum, Desmostachya bipinnata, Phragmites australis, Miscanthus sinensis, Phragmites karka, Typha domingensis and Spartina alterniflora (Abideen et al., 2011; Liu et al., 2012). The perennials are usually preferred due to lesser cost of planting every year and longer canopy duration (Abideen et al., 2011).

Tamarix produces high biomass on non-arable soils irrigated with sewage and brackish water. Several species of Tamarix (T. aphylla, T. jordanis and T. ramosissima) have been reported to survive under harsh conditions of drought and salinity with biomass yields ranging from $\sim 20$ to 52 t/ha/year (Eshel et al., 2010). Eschel et al. (2011) and Santi et al. (2014) tested several species of Tamarix for biomass production and cellulose content, and suggested T. jordanis as a promising candidate due to high cellulose content.

Lignin or its derivatives can inhibit or compromise the cellulase activity and therefore, pose major challenge for the conversion of biomass to ethanol. Therefore, plant species with less lignin in their cell walls are desirable and can reduce the cost involved in biofuel production. In a study conducted with the halophytes, found in the coastal regions of Pakistan, Abideen et al. (2011) reported perennial grasses, Halopyrum mucronatum, Desmostachya bipinnate, Phragmites karka, Typha domingensis and Panicum turgidum as potential species for bioethanol production. These species are estimated to contain $<10 \%$ lignin content, $26-27 \%$ cellulose and $24-38 \%$ hemicellulose in their cell walls (Table 1B).

\section{RECENT DEVELOPMENTS AND OPPORTUNITIES}

Clearly, biofuels offer a sustainable solution to address the environmental issues and would impact social as well as economic benefits. Especially, halophyte-based agriculture, where inputs are marginalized land and saline water from sea, has tremendous potential as biofuel feedstock. With their remarkable ability to tolerate salinity and limited energy costs associated with their production, halophytes have opened much barren land to agriculture. Adapting and improving the yield potential of these plants on the desert lands provide huge opportunities for the reclamation of the dry/saline lands like Sahara desert, Western Australia, Southern Africa, Thar desert and dry lands around the coastal regions. In addition, use of saline water for agriculture and vegetation in these dry lands will boost the ecophysiology, cool the environment, reduce heavy metal toxicity and help in establishing flora and fauna diversity (Lutts and Lefevre, 2015; Long et al., 2016). Moreover, halophytes are also very good experimental system to understand the molecular mechanism of salt tolerance and identify candidate genes for engineering salt tolerance in other conventional crops (Shabala, 2013). Recently, Song and Wang (2015) highlighted the potential of euhalophyte Suaeda salsa as a model system to explore the mechanism of adoption of dimorphic seeds to salinity environment.

An Initiative by Seawater Foundation for Greening Eritrea is a remarkable example of how a desert soil can be converted to a useful resource for agriculture (Ministry of Agriculture, 2002). Located on west coast of Red Sea, Seawater farms Eritrea were the world's first commercial-scale integrated seawater farms. They had performed intercropping of Salicornia with mangroves (Ray and Anumakonda, 2011). Though the project was shut down because of repressive and xenophobic attitude of the government (Mission_2014, 2011); based upon the learning outcomes, Hodge developed another similar project at Mexico and founded Global Seawater Inc. for producing Salicornia based biofuels (Dickerson, 2008). Due to mismanagement of Salicornia production, Global Seawater Inc. could not provide enough biofuel to Mexican airlines for the trial flight in 2010. However, in the meantime, several private and government agencies realized the potential of halophyte-based biomass/food/feed production and made significant investments in this field (O'Keeffe, 2010). The National Aeronautics and Space Administration (NASA) of Unites States of America has constructed a GreenLab research facility for biomass optimization with viable options for alternative energy resources. The halophytic species of their primary focus are Salicornia virginica (grown widely), S. bigelovii (high lipid content), S. euphoraea (tall and large), Rhizophora 
mangle (Red mangrove), Avicennia berminans (Black mangrove) and sea grass (Bomani et al., 2011).

Several airlines have set up a Sustainable Aviation Fuel Users Group and are exploring halophyte-based biofuel production on the marginal lands through seawater agriculture ${ }^{1}$ (accessed August 21, 2016). Boeing, Etihad Airways and Masdar Institute of Science and Technology are working for the development of sustainable aviation biofuel. Their goal is to develop an Integrated Seawater Energy and Agriculture System (ISEAS) where biofuel feedstock will be cultivated with aquaculture and mangrove silviculture. After generating some breakthrough preliminary and exciting data, the consortium is developing about 2000 sq. $\mathrm{km}$ of the desert land in the western region of Abu Dhabi for halophyte farming where sea water will be used for irrigation (Cornwell, 2014). A pilot facility has already been built in this regard. New Nile Co. is also working on the implementation of an Integrated Seawater Agriculture System (ISAS ${ }^{\mathrm{TM}}$ ) that combines the seawater and arid non-agricultural land to produce biofuels, animal fodder and other food products ${ }^{2}$ (accessed on August 21, 2016). S. bigelovii has been proposed as a halophytic species for integrated aqua-agriculture system as it can grow on aquaculture effluents with lots of nutrients and water for irrigation. Further, it has been estimated to produce up to 900 liters of biodiesel per hectare land (Christiansen, 2008) The International Centre for Biosaline Agriculture (ICBA) also, based on their experiments on S. bigelovii in United Arab Emirates (UAE), highlighted its growing potential in Gulf cooperation council countries for biomass and seed production (Shahid and Rao, 2011). ICAB is actively working to identify wide range of salt tolerant crops, analyzing the yield of selected crops on the marginal lands and providing technical support to the farmers through National Agricultural Research Systems of the partner countries (Shahid et al., 2011).

However, in spite of all these successful results and ongoing efforts to screen and identify most suitable halophytic species, there are several challenges down the road for largescale adoption of halophytes as feedstock/food crops. Firstly, identification of region-specific genotypes and adapting them in existing agricultural infrastructure without compromising their yield potential is required (Koyro et al., 2011; Ksouri et al., 2012; Buhmann and Papenbrock, 2013; de Vos et al., 2013; Katsching et al., 2013; Rozema and Schat, 2013; Shpigel et al., 2013). We need to launch appropriate breeding efforts as these plants have never been grown systematically in breeding trials for domestication (Zerai et al., 2010). For example, small size and uneven ripening of the seeds in S. bigelovii can lead to loss of up to $50 \%$ during harvesting therefore, improved mechanical harvesting technology is required. Many halophytic species are intolerant to high concentration of salts during germination and seedling establishment. Therefore, transplanting of seedlings or stem cuttings is practiced that needs optimum growth conditions, on-site fresh water resources and stock plant management.

Further, accumulation of inorganic salts in biomass that helps plants to adapt to saline environment can complicate

\footnotetext{
${ }^{1}$ http://www.safug.org/

${ }^{2} \mathrm{http} / / /$ www.newnileco.com
}

both thermochemical and biochemical conversion for biofuel production. Efficient processing of halophyte-based biomass requires significant investments and efforts from the scientific community to increase saccharification efficiency, reduce ash content and development of other byproducts (Brown et al., 2014). Though modern genome editing tools or transgenic technologies can expedite the halophyte improvement for reduced accumulation of inorganic salts, we would need to ensure that tailoring halophytes for optimizing biofuel-related traits does not compromise on their ability to grow in salinity affected areas and, ward off pathogens and pests. Screening germplasm for the traits of interest would be a good approach to exploit already existing genetic diversity and select best genotypes.

However, the key experimental model systems namely, Arabidopsis and rice, for which extensive genetic and genomic resources have been developed, are glycopytes. With the advent of next generation sequencing technologies, whole genomes of candidate halophytes have been sequenced (Yang et al., 2013) while RNAseq followed by de novo assembly has been used for gene expression profiling in halophytes (Tsukagoshi et al., 2015; Wang et al., 2015; Jin et al., 2016). However, we need to generate concrete genetic and genomic resources for halophytic models to better understand the mechanism of salt tolerance and physiology of halophytes. Also, little information is available about the potential pathogens of halophytes when grown at large scales.

Overall, identification of region-specific halophytes, accessibility to seeds, development of halophyte nurseries, optimizing cultural practices (planting methods, fertilizer requirements, insect-pest management), establishment of processing plants and development of new landscape management system are immediate requirements to develop saline agriculture for bioenergy crops. Plant breeders and molecular biologists would have to join hands to expedite the process of incorporation of desirable changes in the plant makeup that are imperative for fuel, production of additional high value products and improve their yield potential in terms of oil content, seed yield and lignocellulosic biomass. Since, large-scale planting of halophytes has not been attempted, only time will unveil the practical challenges associated with halophyte farming and guide future research directions.

\section{AUTHOR CONTRIBUTIONS}

MS and RS conceptualised, prepared the framework and wrote the review. SW and VS collected the literature and prepared the table. AP helped in preparing the framework and finalising the article. All authors approved the article.

\section{FUNDING}

MS and RS acknowledge the Ramalingaswami fellowship by the Department of Biotechnology, Government of India. SW acknowledges Junior Research Fellowship (JRF) and UPOEII project grant. VS acknowledges Indian Council of Medical Research (ICMR) for Junior Research Fellowship. 


\section{REFERENCES}

Abideen, Z., Ansari, R., Gul, B., and Khan, M. A. (2012). The place of halophytes in Pakistan's biofuel industry. Biofuels 3, 211-220. doi: 10.4155/bfs. 11.158

Abideen, Z., Ansari, R., and Khan, M. A. (2011). Halophytes: potential source of ligno-cellulosic biomass for ethanol production. Biomass Bioenergy 35, 1818 1822. doi: 10.1016/j.biombioe.2011.01.023

Abideen, Z., Hameed, A., Koyro, H.-W., Gul, B., Ansari, R., and Khan, M. A. (2014). Sustainable biofuel production from non-food sources - An overview. Emir. J. Food Agric. 26, 1057-1066. doi: 10.9755/ejfa.v26i12.19107

Aronson, J. A., and Whitehead, E. E. (1989). Haloph: A Data Base of Salt Tolerant Plants of the World. Tucson, Az: Office of Arid Lands Studies, University of Arizona.

Atia, A., Debez, A., Barhoumi, Z., Abdelly, C., and Smaoui, A. (2010). Localization and composition of seed oils of Crithmum maritimum L. (Apiaceae). Afr. J. Biotechnol. 9, 6482-6485.

Bell, H. L., and O'Leary, J. W. (2003). Effects of salinity on growth and cation accumulation of Sporobolus virginicus (Poaceae). Am. J. Bot. 90, 1416-1424. doi: 10.3732/ajb.90.10.1416

Blackshaw, R., Johnson, E., Gan, Y., May, W., McAndrew, D., Barthet, V., et al. (2011). Alternative oilseed crops for biodiesel feedstock on the Canadian prairies. Can. J. Plant Sci. 91, 889-896. doi: 10.4141/cjps2011-002

Bomani, B. M. M., Hendricks, R. C., Elbluk, M., Okon, M., Lee, E., and Gigante, B. (2011). NASA's GreenLab Research Facility- A Guide for a Self-Sustainable Renewable Energy Ecosystem. Available at: http://ntrs.nasa.gov/archive/nasa/ casi.ntrs.nasa.gov/20120001794.pdf

Boyko, H. (1967). Salt water agriculture. Sci. Am. 216, 89-96.

Brosse, N., Dufour, A., Meng, X., Sun, Q., and Ragauskas, A. (2012). Miscanthus: a fast-growing crop for biofuels and chemicals production. Biofuels Bioprod. Biorefin. 6, 580-598. doi: 10.1002/bbb.1353

Brown, J. J., Cybulska, I., Chaturvedi, T., and Thomsen, H. (2014). "Halophytes for the production of liquid biofuels," in Sabkha Ecosystems: Vol. IV, Cash Crops Halophyte and Biodiversity Conservation: Task for Vegetation Science Series, eds M. A. Khan, B. Böer, M. Öztürk, T. Z. Al Abdessalaam, M. Clüsener-Godt, and B. Gul (Dordrecht: Springer Science+Business Media), 47, 67-72.

Buhmann, A., and Papenbrock, J. (2013). An economic point of view of secondary compounds in halophytes. Funct. Plant Biol. 40, 952-967.

Cassaniti, C., and Romano, D. (2011). The use of halophytes for Mediterranean landscaping. Proceedings of the European COST Action FA901. Eur. J. Plant Sci. Biotechnol. 5, 58-63.

Cassaniti, C., Romano, D., Hop, M. E. C. M., and Flowers, T. J. (2013). Growing floricultural crops with brackish water. Environ. Exp. Bot. 92, 165-175. doi: 10.1016/j.envexpbot.2012.08.006

Chen, P., and He, W. S. (2011). The effects of different fertilization structures on yields of sunflower in saline alkali soil. Agric. Res. Arid Areas 29, 108-114.

Christiansen, R. C. (2008). Sea Asparagus Can be Oil Feedstock. Available at: http://www.biodieselmagazine.com/articles/2600/sea-asparagus-can-be-oilfeedstock [accessed August 21, 2016].

Chundawat, S. P., Beckham, G. T., Himmel, M. E., and Dale, B. E. (2011). Deconstruction of lignocellulosic biomass to fuels and chemicals. Annu. Rev. Chem. Biomol. Eng. 2, 121-145. doi: 10.1146/annurev-chembioeng-061010114205

Cornwell, A. (2014). Etihad and Boeing to Fund Uae Biofuel Farm. Available at: http://projects.zawya.com/Etihad_and_Boeing_to_fund_UAE_biofuel_farm/ story/GN_22012014_230127/ [accessed August 21, 2016].

de Vos, A. C., Broekman, R., de Almeida, G. C. C., van Rijsselberghe, M., and Rozema, M. (2013). Developing and testing new halophyte crops: a case study of the salt tolerance of two species of the Brassicaceae, Diplotaxis tenuifolia and Cochlearia officinalis. Environ. Exp. Bot. 92, 154-164.

Dickerson, M. (2008). Letting the Sea Cultivate the Land. Los Angeles Times. Available at: http://articles.latimes.com/2008/jul/10/business/fi-seafarm 10 [accessed August 21, 2016].

Du, X., Li, P., and Guan, F.-C. (2009). The efficient cultivation techniques of Suaeda glauca bunge in protected field. J. Jilin Agric. Sci. 34, 52-53.

Eschel, A., Oren, I., Alekparov, C., Eilam, T., and Zilberstein, A. (2011). EschelBiomass production by desert halophytes- alleviating the pressure on the scarce resources of arable soil and fresh water. Eur. J. Plant Sci. Biotechnol. 5, 48-53.
Eshel, A., Zilberstein, A., and Alekparov, C. (2010). "Biomass production by desert halophytes: alleviating the pressure on food production," in Proceedings of the 5th IASME/WSEAS International Conference on Energy and Environment. Recent Advances in Energy and Environment, Cambridge, $362-367$.

Flowers, T. J., and Colmer, T. D. (2008). Salinity tolerance in halophytes. New Phytol. 179, 945-963. doi: 10.1111/j.1469-8137.2008.02531.x

Foley, J. A., Defries, R., Asner, G. P., Barford, C., Bonan, G., Carpenter, S. R., et al. (2005). Global consequences of land use. Science 309, 570-574. doi: $10.1126 /$ science. 1111772

Gallagher, J. L. (1985). Halophytic crops for cultivation at seawater salinity. Plant Soil 89, 323-336.

Glenn, E., Hicks, N., Riley, J., and Swingle, R. (1996). "Seawater irrigation of halophytes for animal feed," in Halophytes and Biosaline Agriculture, eds R. Chakour-Allah, C. V. Malcolm, and A. Hamdy (New York, NY: Marcel Dekker), 221-236.

Glenn, E. P., Brown, J. J., and Blumwald, E. (1999). Salt tolernace and crop potential of halophytes. Crit. Rev. Plant Sci. 18, 227-255.

Glenn, E. P., Brown, J. J., and O'Leary, J. W. (1998). Irrigating crops with seawater. Sci. Am. 279, 76-81. doi: 10.1155/2013/409413

Gul, B., Abideen, Z., Ansari, R., and Khan, M. A. (2013). Halophytic biofuels revisted. Biofuels 4, 575-577.

Hadar, Y. (2013). "Sources for lignocellulosic raw materials for the production of ethanol," in Lignocellulose Conversion, ed. V. Faraco (Berlin: Springer), 21-38.

Hasanuzzaman, M., Nahar, K., Alam, M. M., Bhowmik, P. C., Hossain, M. A., Rahman, M. M., et al. (2014). Potential use of halophytes to remediate saline soils. Biomed. Res. Int. 2014:589341. doi: 10.1155/2014/5 89341

Hastilestari, B. R., Mudersbach, M., Tomala, F., Vogt, H., Biskupek-Korell, B., Van Damme, P., et al. (2013). Euphorbia tirucalli L.-comprehensive characterization of a drought tolerant plant with a potential as biofuel source. PLoS ONE 8:e63501. doi: 10.1371/journal.pone.0063501

He, Z. C. R., Qin, P., Seliskar, D. M., and Gallagher, J. L. (2003). Kosteletzkya virginica, a halophytic species with potential for agroecotechnology in Jiangsu Province, China. Ecol. Eng. 21, 271-276. doi: 10.1016/j.ecoleng.2004. 01.001

Jin, H., Dong, D., Yang, Q., and Zhu, D. (2016). Salt-responsive transcriptome profiling of Suaeda glauca via RNA sequencing. PLOS ONE 11:e0150504. doi: 10.1371/journal.pone.0150504

Katsching, D., Broekman, R., and Rozema, J. (2013). Salt tolerance in the halophyte Salicornia dolichostachya moss: growth, morphology and physiology. Environ. Exp. Bot. 92, 32-42.

Kennedy, D. (2007). The biofuels conundrum. Science 316:515. doi: 10.1126/ science. 1142978

Khaleghian, A., Nakaya, Y., and Nazari, H. (2011). Biodiesel production from Euphorbia tirucalli L. J. Med. Plants Res. 5, 4968-4973. doi: 10.1371/journal. pone.0063501

Koonin, S. E. (2006). Getting serious about biofuels. Science 311:435. doi: $10.1126 /$ science. 1124886

Koyro, H. W., Khan, M. A., and Lieth, H. (2011). Halophytic crops: a source for the future to reduce the water crisis? Emir. J. Food Agric. 23, 1-6.

Ksouri, R., Smaoui, A., Isoda, H., and Abdelly, C. (2012). Utilization of halophyte species as new sources of bioactive substances. J. Arid Land Stud. 22, 41-44.

Ladeiro, B. (2012). Saline Agriculture in the 21st Century: Using salt contaminanted resources to cope food requirements. J. Bot. 2012:310705. doi: $10.1155 / 2012 / 310705$

Liu, X. Z., Wang, C. Z., Su, Q., and Lib, C. K. (2012). The potential resource of halophytes for developing bio-energy in China coastal zone. Herald J. Agric. Food Sci. Res. 1, 44-51.

Long, X. H., Liu, L. P., Shao, T. Y., Shao, H. B., and Liu, Z. P. (2016). Developing and sustainably utilize the coastal mudflat areas in China. Sci. Total Environ. 56, 1077-1086. doi: 10.1016/j.scitotenv.2016.06.170

Lutts, S., and Lefevre, I. (2015). How can we take advantage of halophyte properties to cope with heavy metal toxicity in salt-affected areas? Ann. Bot. 115, 509-528. doi: $10.1093 / \mathrm{aob} / \mathrm{mcu} 264$

Malcolm, C. V. (1969). Use of halophytes for forage production on saline wastelands. J. Aust. Inst. Agric. Sci. 35, 38-49. 
McLaughlin, S. B., and Kszos, L. A. (2005). Development of switchgrass (Panicum virgatum) as a bioenergy feedstock in the United States. Biomass Bioenergy 28, 515-535. doi: 10.1016/j.biombioe.2004.05.006

Ministry of Agriculture (2002). The National Action Programme for Eritrea to Combat Desertifcation and Mitigate the Effects of Drought. Asmara: Ministry of Agriculture. Available at: http://www.unccd.int/ActionProgrammes/eritreaeng2002.pdf [accessed March 21, 2016].

Mission_2014 (2011). Mission 2014: Feeding the World. Available at: http://12.000. scripts.mit.edu/mission2014/solutions/seawater-farming

Mo, X.-Q., and Li, H.-Y. (2010). Application of wild halophytes in Tianjin coastal wetland. Urban Environ. Urban Ecol. 2, 14-17.

Moser, B. R., Dien, B. S., Seliskar, D. M., and Gallagher, J. L. (2013). Seashore mallow (Kosteletzkya pentacarpos) as a salt-tolerant feedstock for production of biodiesel and ethanol. Renew. Energy 50, 833-839. doi: 10.1016/j.renene.2012.08.016

Naik, S. N., Goud, V. V., Rout, P. K., and Dalai, A. K. (2010). Production of first and second generation biofuels: a comprehensive review. Renew. Sustain. Energy Rev. 14, 578-597. doi: 10.1016/j.rser.2009.10.003

Nielsen, P. E., Nishimura, H., Otvos, J. W., and Calvin, M. (1977). Plant crops as a source of fuel and hydrocarbon-like materials. Science 198, 942-944. doi: $10.1126 /$ science. 198.4320 .942

O'Keeffe, N. (2010). Aviation Biofuels: the Bumpy Road to Scale Production, FightGlobal. Available at: https://www.flightglobal.com/news/articles/aviation -biofuels-the-bumpy-road-to-scale-production-338613/ [accessed August 21, 2016].

O'leary, J. W., and Glenn, E. P. (1994). "Global distribution and potential for halophytes," in Halophytes as a Resource for Livestock and for Rehabilitation of Degraded Lands, eds V. R. Squires and A. T. Ayoub (Dordrecht: Kluwer academic), 7-17.

Panta, S., Flowers, T., Lane, P., Doyle, R., Haros, G., and Shabala, S. (2014). Halophyte agriculture: success stories. Environ. Exp. Bot. 107, 71-83. doi: 10.1016/j.envexpbot.2014.05.006

Parida, A. K., and Das, A. B. (2005). Salt tolerance and salinity effect on plants: a review. Ecotoxicol. Environ. Saf. 60, 324-349. doi: 10.1016/j.ecoenv.2004. 06.010

Pasternak, D., Danon, A., Aronson, J. A., and Benjamin, R. W. (1985). Developing the sea- water agriculture concept. Plant Soil 89, 337-348. doi: 10.1007/BF02182252

Peng, L., Yi, Y., Fu-li, G., and Ze-qu, L. (1997). A preliminary study on the introduction of Descurainia sophia, an oil plant species for industrial uses. J. Integr. Plant Biol. 39, 477-479.

Qadir, M., Quillerou, E., Nangia, V., Murtaza, G., Singh, M., Thomas, R. J., et al. (2014). Economics of salt-induced land degradation and restoration. Nat. Resour. Forum 38, 282-295. doi: 10.1111/1477-8947.12054

Qadir, M., Tubeileh, A., Akhtar, J., Larbi, A., Minhas, P. S., and Khan, M. A. (2008). Productivity enhancement of salt-affected environments through crop diversification. Land Degrad. Dev. 19, 429-453. doi: 10.1002/ ldr. 853

Ray, A., and Anumakonda, A. (2011). "Production of green liquid hydrocarbon fuels," in Biofuels: Alternative Feedstocks and Conversion Processes, eds A. Pandey, C. Larroche, S. C. Ricke, C. G. Dussap, and E. Gnansounou (Cambridge, MA: Academic Press).

Rozema, J., and Flowers, T. (2008). Ecology. Crops Salinized world Sci. 322, 1478-1480. doi: 10.1126/science. 1168572

Rozema, J., and Schat, H. (2013). Salt tolerance of halophytes, research questions reviewed in the perspective of saline agriculture. Environ. Exp. Bot. 92, 83-95. doi: 10.1016/j.envexpbot.2012.08.004

Ruan, C. J., Li, H., Guo, Y. Q., Qin, P., Gallagher, J. L., Seliskar, D. M., et al. (2008). Kosteletzkya virginica, an agroecoengineering halophytic species for alternative agricultural production in China's east coast: ecological adaptation and benefits, seed yield, oil content, fatty acid and biodiesel properties. Ecol. Eng. 32, 320-328. doi: 10.1016/j.ecoleng.2007.12.010

Sabovljevic, M., and Sabovljevic, A. (2007). Contribution to the coastral bryophytes of the northern mediterranean: are ther halophytes amongh bryophytes. Phytol. Balcanica 13, 131-135.

Sagar, A. D., and Kartha, S. (2007). Bioenergy and sustainable development. Аnnu. Rev. Environ. Resour. 32, 131-167. doi: 10.1146/annurev.energy.32. 062706.132042
Santi, G., D’Annibale, A., Eshel, A., Zilberstein, A., Crognale, S., Ruzzi, M., et al. (2014). Ethanol production from xerophilic and salt-resistant Tamarix jordanis biomass. Biomass Bioenergy 61, 73-81. doi: 10.1016/j.biombioe.2013.11.024

Santos, J., Al-Azzawi, M., Aronson, J., and Flowers, T. J. (2016). eHALOPH a database of salt-tolerant plants: helping put Halophytes to work. Plant Cell Physiol. 57:e10. doi: 10.1093/pcp/pcv155

Shabala, S. (2013). Learning from halophytes: physiological basis and strategies to improve abiotic stress tolerance in crops. Ann. Bot. 112, 1209-1221. doi: $10.1093 / \mathrm{aob} / \mathrm{mct} 205$

Shahi, M., Saaghari, M., Esfahan, E. Z., and Jaimand, K. (2013). Investigation on potential of Suaeda fruticosa as a source of edible oil. J. Biodivers. Environ. Sci. 3, 101-107.

Shahid, M., and Rao, N. K. (2011). Salicornia bigelovii: a versatile crop for the seawater agriculture. Biosalinity News 12, 6.

Shahid, S. A., Taha, F. K., Ismail, S., Dakheel, A., and Abdelfattah, M. (2011). "Turning adversity into an advantage for food security through improving soil quality and providing production systems for marginal saline lands: ICBA perspectives and approach," in Sustainable Agricultural Development, eds M. Behnassi, S. A. Shahid, and J. D'Silva (Berlin: Springer).

Shpigel, M., Ben-Ezra, D., Shauli, L., Ventura, Y., Samocha, T., and Lee, J. J. (2013). Constructed wetland with Salicornia as a biofilter for mariculture effluents. Aquaculture 41, 52-63. doi: 10.1016/j.aquaculture.2013.06.038

Simmons, B. A., Loque, D., and Blanch, H. W. (2008). Next-generation biomass feedstocks for biofuel production. Genome Biol. 9:242. doi: 10.1186/gb-2008-9$12-242$

Song, J., and Wang, B. (2015). Using euhalophytes to understand salt tolerance and to develop saline agriculture: Suaeda salsa as a promising model. Ann. Bot. 115, 541-553. doi: 10.1093/aob/mcu194

Squires, V. R., and Ayoub, A. T. (1994). "Halophytes as a resource for livestock and for rehabilitation of degraded lands," in Proceedings of the International Workshop on Halophytes for Reclamation of Saline Wastelands and as a Resource for Livestock Problems and Prospects, Nairobi.

Touchette, B. W., Smith, G. A., Rhodes, K. L., and Poole, M. (2009). Tolerance and avoidance: two contrasting physiological responses to salt stress in mature marsh halophytes Juncus roemerianus Scheele and Spartina alterniflora Loisel. J. Exp. Mar. Biol. Ecol. 380, 106-112. doi: 10.1016/j.jembe.2009. 08.015

Tsukagoshi, H., Suzuki, T., Nishikawa, K., Agarie, S., Ishiguro, S., and Higashiyama, T. (2015). RNA-seq analysis of the response of the halophyte, Mesembryanthemum crystallinum (ice plant) to high salinity. PLoS ONE 10:e0118339. doi: 10.1371/journal.pone.0118339

van der Weijde, T., Alvim Kamei, C. L., Torres, A. F., Vermerris, W., Dolstra, O., Visser, R. G., et al. (2013). The potential of C4 grasses for cellulosic biofuel production. Front. Plant Sci. 4:107. doi: 10.3389/fpls.2013.00107

Ventura, Y., Eshel, A., Pasternak, D., and Sagi, M. (2014). The development of halophyte-based agriculture: past and present. Ann. Bot. 115, 529-540. doi: $10.1093 / \mathrm{aob} / \mathrm{mcu} 173$

Wang, J., Li, B., Meng, Y., Ma, X., Lai, Y., Si, E., et al. (2015). Transcriptomic profiling of the salt-stress response in the halophyte Halogeton glomeratus. BMC Genomics 16:169. doi: 10.1186/s12864-015-1373-z

Wang, L., Baskin, J. M., Baskin, C. C., Cornelissen, J. H., Dong, M., and Huang, Z. (2012). Seed dimorphism, nutrients and salinity differentially affect seed traits of the desert halophyte Suaeda aralocaspica via multiple maternal effects. BMC Plant Biol. 12:170. doi: 10.1186/1471-2229-12-170

Weber, D. J., Ansari, R., Gul, B., and Ajmal Khan, M. (2007). Potential of halophytes as source of edible oil. J. Arid Environ. 68, 315-321. doi: 10.1016/j.jaridenv.2006.05.010

Weber, D. J., Bilquees, G., Khan, M. A., Williams, T., Wayman, P., and Warner, S. (2001). "Composition of vegetable oil from seeds of native halophytic shrubs," in Proceedings of the Conference: Shrubland Ecosystem Genetics and Biodiversity, 287-290. Available at: http://www.fs.fed.us/rm/pubs/rmrs_ p021/rmrs_p021_287_290.pdf [accessed August 21, 2016].

Xian-zhao, L., Chun-zhi, W., Qing, S., and Chao-kui, L. (2012). he potential resource of halophytes for developing bio-energy in China coastal zone. J. Agric. Food Sci. Res. 1, 044-051.

Yan, M., Pan, G. X., Li, L. Q., and Zou, J. W. (2010). An overview of the potential role of reed (Phragmites australis) wetlands in terrestrial carbon sequestration of China. Chin. Agric. Sci. Bull. 26, 320-323. 
Yang, R., Jarvis, D. E., Chen, H., Beilstein, M. A., Grimwood, J., Jenkins, J., et al. (2013). The reference genome of the Halophytic plant Eutrema salsugineum. Front. Plant Sci. 4:46. doi: 10.3389/fpls.2013. 00046

Zerai, D. B., Glenn, E. P., Chatervedi, R., Lu, Z., Mamood, A. N., Nelson, S. G., et al. (2010). Potential for the improvement of Salicornia bigelovii through selective breeding. Ecol. Eng. 36, 730-739. doi: 10.1016/j.ecoleng.2010. 01.002

Zhou, G., Ma, B. L., Li, J., Feng, C., Lu, J., and Qin, P. (2010). Determining salinity threshold level for castor bean emergence and stand establishment. Crop Sci. 50, 2030-2036. doi: 10.2135/cropsci2009.09.0535
Conflict of Interest Statement: The authors declare that the research was conducted in the absence of any commercial or financial relationships that could be construed as a potential conflict of interest.

Copyright (c) 2016 Sharma, Wungrampha, Singh, Pareek and Sharma. This is an open-access article distributed under the terms of the Creative Commons Attribution License (CC BY). The use, distribution or reproduction in other forums is permitted, provided the original author(s) or licensor are credited and that the original publication in this journal is cited, in accordance with accepted academic practice. No use, distribution or reproduction is permitted which does not comply with these terms. 